\title{
LONG-TERM GLACIER VARIATIONS MEASURED BY PHOTOGRAMMETRY. A RE-SURVEY OF TUNSBERGDALSBREEN AFTER 24 YEARS
}

\author{
By W. KICK \\ (Macheinerweg 35, Regensburg, Germany)
}

\begin{abstract}
Aвstract. The relations between geodetic measurements of the surface level variations $\Delta h$ and net budget measurements by stakes are discussed. In $196 \mathrm{r}, 24 \mathrm{yr}$. after Finsterwalder's survey, Tunsbergdalsbreen, the largest and most regular of the 26 outlet glaciers of Jostedalsbreen, was re-surveyed. The variations in the length, area, ice thickness, and volume of its tongue are shown. The lake Brimkjelen was $99 \mathrm{~m}$. deep in 1937; it disappeared in 1949 . From $1900-40$ the whole Jostedalsbre lost $0.4 \mathrm{~m}$./yr., about the same amount as the glaciers of the eastern Alps. The ice thickness of the Tunsbergdalsbre tongue diminished by $-\Delta h_{A}=0.46+0.0022(1500-A) \mathrm{m}$. $/ \mathrm{yr}$. from $1937-6 \mathrm{I} ;$ for the eastern Alps from $1920-50$ $-\Delta h_{A} \approx 0.53+0.002 \mathrm{I}(2850-A) \mathrm{m}$. $/ \mathrm{yr}$., where $A$ is the altitude. The change of $\Delta h$ with altitude is much the same. The amounts of the retreat of the Alpine glaciers, of Tunsbergdalsbreen, and at Werenskioldbreen, Vestspitsbergen, were the greater the higher the latitude. The numerical relations between $\Delta h$, net budget, and ice movement are shown. The temporary velocity transverse profile of 1937 served as a prototype for the streaming mode of flow, but in $196 \mathrm{I}$ the glacier partially showed Blockschollen movement, although the velocity had decreased by more than 30 per cent. The article is accompanied by a map showing ice surface contours in 1937 and $196 \mathrm{I}$.
\end{abstract}

RÉsumé. Variations de longue durée des glaciers mesurées par photogrammetrie. Nouveau relevé du Tunsbergdalsbre après 24 années. Les relations entre les variations du niveau $\Delta h$ mesurées par des méthodes géodésiques et les budgets nets mesurés par des balises sont discutées. Le Tunsbergdalsbre, le plus long et particulièrement régulier parmi les 26 glaciers de décharge du Jostedalsbre a été remesuré par photogrammétrie terrestre en 1961, 24 ans après le relevé de Finsterwalder. Les variations de sa langue en longitude, aire, épaisseur et volume sont montrées. Le Lac Brimkjelen en 1937 avait une épaisseur de $99 \mathrm{~m}$, et a disparu depuis 1949 . Entre $1900-40$, tout le Jostedalsbre avait perdu $0,4 \mathrm{~m} / \mathrm{an}$, les glaciers des Alpes Orientales à peu près la même valeur $(0,45 \mathrm{~m} / \mathrm{an})$. Entre ${ }_{1937-61}$ l'épaisseur de la langue du Tunsbergdalsbre a diminué pour $-\Delta h_{A}=0,46+0,0022(1500-A) \mathrm{m} / \mathrm{an}(A=$ altitude); entre $1920-50$ pour les Alpes Orientales, $-\Delta h_{A} \approx 0,53+0,002 \mathrm{I}(2850-A) \mathrm{m} / \mathrm{an}$. La variation de $\Delta h$ a été la même. La récession des glaciers Alpins, du Tunsbergdalsbre et du Werenskioldbre, Vestspitsbergen, a été plus grande aux latitudes plus hautes. La relation entre $\Delta h$, l'ablation nette et la vitesse à la surface est montrée. Le profil tranversal de la vitesse de I937 a été un prototype de l'écoulement continu, mais en r96I un côté montra le mouvement par bloc, quoique la vitesse ait diminué pour plus de $30 \%$.

\begin{abstract}
Zusammenfassung. Photogrammetrische Messung langfristiger Gletscheränderungen. Wiederholungsaufnehme des Tunsbergdalsbre nach 24 Jahren. Die Beziehungen zwischen den geodätisch gemessenen Eisdickenänderungen $\Delta h$ zu den mit Pegeln gemessenen örtlichen Massenbilanzen werden erörtert. Die $\Delta h$ für die Ablationsgebiete allein, oder nur für die Gebiete an der Firnlinie, können unter bestimmten Umständen für die Änderungen des ganzen Gletschers repräsentativ sein. Der Tunsbergdalsbre als grösster und besonders regelmässiger unter den 26 Abflussgletschern des Jostedalsbre wurde 24 Jahre nach Finsterwalders Aufnahme 1961 photogrammetrisch wiedervermessen. Die Änderungen seiner Zunge in Länge, Fläche, Eisdicke und Volumen. Der 1949 ausgelaufene Gletscherstausee Brimkjelen war $193799 \mathrm{~m}$ tief; $1900-40$ hat der gesamte Jostedalsbre um $0,4 \mathrm{~m} / \mathrm{J}$ verloren, die Gletscher der Ostalpen um den gleichen Betrag. 1937-6 I verminderte sich die Eisdicke der Tunsbergdalsbre-Zunge um $-\Delta h_{A}=0,46+0,0022(1500-A) \mathrm{m} / \mathrm{J}$ ( $A=$ Meereshöhe), 1920-50 die der Ostalpengletscher um $-\Delta h_{A} \approx 0,53+0,002 \mathrm{I}(2850-A) \mathrm{m} / \mathrm{J}$. Die Änderung der $\Delta h \mathrm{mit}$ der Meereshöhe war gleich gross. Das Ausmass des Rückgangs an den Alpengletschern, am Tunsbergdalsbre und am Werenskioldgletscher, Spitzbergen, war umso grösser, in je höherer Breite das Gebiet liegt. Zahlenmässiger Zusammenhang zwischen $\Delta h$, Netto-Ablation und Oberflächengeschwindigkeit. Das Geschwindigkeitsquerprofil war 1937 typisch für strömende Bewegung, wogegen Ig6r die eine Seite Blockbewegung zeigte, obwohl die Geschwindigkeit um über 30\% kleiner geworden war. Dem Artikel ist eine Karte mit dem Höhenlinienbild des Gletschers von 1937 und 196 I beigegeben.
\end{abstract}

\section{i. The Significance of Geodetic Measurements of Glacier Variations}

The Würm Ice Age lasted some I20,000 yr. and finished only some Io,ooo yr. ago. Today only the remains can be studied. But even today one-tenth of the land areas of the earth is still or again covered with ice and offers us the opportunity of studying in our times the course of this phenomenon and its relations to climatological changes while these are actually happening.

For the Alps we know from historical records that in the beginning of the seventeenth century the glaciers advanced and reached an extent larger than for many earlier centuries, 
perhaps millennia. This larger extent seems to have lasted with only secondary variations for almost two and a half centuries. The end of it had come by $1850-55$. Since that time-or in some exceptional cases some years later - the many hundreds of glaciers in all parts of the Alps have been retreating and are still retreating.

In recent years more and more dates of glacier variations of all zones and regionsrecessions prevailing - have become available. But for the large majority they only concern the variations of the terminus, that is the changing of the length of the glaciers. The figures of these length variations are valuable, as normally a large number of them indicate a clear general trend for a whole glacierized district, but the amounts of the single values vary too much for the various individual glaciers, to provide a mean figure significant for a larger geographic unit, and their second still more serious disadvantage consists in their rather complicated relation to the mass budget of the ice bodies.

Geodetic measurements of glacier variations should serve two purposes: first their results should state the phenomena in a numerical and comparable way and secondly they should contribute as much as possible to the elucidation of the reasons for the variations. For this latter purpose they will help most if their geometrical result is a simple function of the quantitative meteorological data, in this case of the balance of accumulation and ablation of the glacier concerned.

Among the geometrical measures of these variations the mean change $\Delta h_{\mathrm{m}}$ of the surface level averaged for the whole glacier is the one which serves the two purposes best. The late Professor R. Finsterwalder has shown that for some ten glaciers in various parts of the eastern Alps and for some decades this $\Delta h_{\mathrm{m}}$ does not vary much for the individual glaciers and therefore its mean $\Delta H_{\mathrm{m}}$ as the average of some typical and well distributed single glaciers is a rather representative figure for a whole geographic district such as the eastern Alps (Finsterwalder, I953, I954). By multiplying $\Delta h_{\mathrm{m}}$ by the more easily measured area $S$, we get the variation $\Delta V$ of the glacier's volume. The exact relation is

$$
\Delta V=S \Delta h_{\mathrm{m}}+\Delta S h_{\mathrm{m} \Delta S}
$$

where $S$ is the smaller of the two areas $S_{\mathrm{I}}$ and $S_{2}$ corresponding to the times $t_{1}$ and $t_{2}$ at which the geodetic measurements were taken, and $h_{\mathrm{m} \Delta S}$ is the mean ice thickness over the area $\Delta S$ which has been added or lost in this time interval. The second term is generally much smaller than the first. In the case of Tunsbergdalsbreen it amounts to only 5 per cent of $\Delta V$ ( I937-6r). Therefore $S \Delta h_{\mathrm{m}}$ approximately represents the variation in volume

$$
\Delta V \approx S \Delta h_{\mathrm{m}} .
$$

The quantity $\Delta h_{\mathrm{m}}$ and its mean $\Delta H_{\mathrm{m}}$ are also the most useful geometric quantities for the second purpose mentioned above. The relation between $\Delta h_{i}$, the vertical change of surface level relative to a constant datum level measured by geodetic means such as photogrammetry, and the specific net budget for a given surface element $i$ is given by the relation

$$
h_{i}=b_{i}-\left(a_{i}\right)-\left(d_{i}\right)+z_{i}
$$

where $b$ is the local specific net budget at the surface as measured by stakes, i.e. is the accumulation $c$ minus the ablation $a,(a)$ is the lowering of the surface due to basal and internal ablation, $(d)$ is the lowering of the surface due to changes of density with time, and $z$ is the vertical movement of the former surface due solely to ice motion, i.e. the vertical movement which would occur if there were no ablation or accumulation. These quantities all refer to the same time interval $t_{2}-t_{\mathrm{I}}$, generally several years long, and are usually divided by the interval so as to be expressed in units of millimetres per year or metres per year; the definitions are mainly according to Meier (1 96o, p. 20; 1962, p. 254; Meier and Tangborn, 1965, p. 558-65); the use of $\Delta h$ follows that of Finsterwalder and Haefeli.

The neglect of (a) may be justified as its amount seems to be small compared with that of the surface ablation. The effect $(d)$ of the change in density may be neglected for the ablation 
area, the density there being sufficiently constant near $0.9 \mathrm{I}$ g. $/ \mathrm{cm} .^{3}$. For the accumulation area the geodetic and the stake measurements need to be supplemented by the determination of the density of the upper layers - varying between 0.5 and $0.9 \mathrm{~g} . / \mathrm{cm} .{ }^{3}$ - in order to transfer their results into the comparable water-equivalent. To compare annual balances, only the differences in density at the times compared need be known. To a first approximation then,

$$
\Delta h_{i}=b_{i}+z_{i}
$$

While $b_{i}$ represents the balance of accumulation and ablation, the variation in ice thickness $\Delta h_{i}$ results as another balance, namely that of $b_{i}$ and the vertical component $z_{i}$ of the ice motion which tends to compensate the mass exchange $b_{i}$ between the glacier and its surroundings occurring through the surface.

For the whole glacier

$$
\rho \Delta V=B
$$

where $\rho$ is an average density transferring the volume variations of ice, firn, and snow into units of water-equivalent, and $B$ is the water-equivalent net budget total.

Using ( $\mathrm{r}$ a) we find

$$
\Delta h_{\mathrm{mw}}=\rho \Delta V / S=B / S=b
$$

where $\Delta h_{\mathrm{m} w}$ is the water-equivalent of $\Delta h_{\mathrm{m}}$.

As a first approximation the geodetic result $\Delta h_{\mathrm{m} w}$ for the whole glacier corresponds to the mean specific net budget $b$ defined as the total net budget $B$ divided by the surface area $S$.

The same relation results from $(2 \mathrm{a})$ : by assuming a constant volume (without accumulation and ablation according to the definition of $z$ ), and a constant area $S$, the summing of $z$ over the whole area must be

and hence we get ( $3 a)$.

$$
\int z d S=0
$$

An investigation of the correlations between the results of the geodetic and those of the meteorological measurements is being made at present, using the data for a series of years for certain Alpine glaciers. It may provide an empirical mean correction factor for transferring the volume changes into the water-equivalent and in this may render usable quite a lot of photogrammetric measurements of glacier variations already to hand for meteorological (net budget) conclusions. While detailed meteorological and hydrological analysis is necessary for the fundamental elucidation of the relations between climate and glaciers-providing the components of the mass balance $b$ and the corresponding elements of the climate and of radiation - the photogrammetric measurements give $\Delta h$ and hence the variation in the volume of the glaciers. Photogrammetry as a more extensive and summarizing method, may extend the meteorological results to the longer-term variations and to their geographical distribution on the Earth. A better knowledge of the climatological variations and their effect on glaciers requires a combined utilization of both methods. Equation (2) shows the contribution of the photogrammetric and that of the stakes measurements.

Theory and experience confirm that the firn regions of valley glaciers are changing their surface levels to a much smaller degree than the ablation areas. An unpublished investigation of the data of variations of ten typical east Alpine glaciers, which Finsterwalder and his school have collected, gave as a result that the measurements of the ablation areas alone would have been sufficient to deliver a figure representative for the glacier retreat in the eastern Alps. The values $\Delta h_{\text {ma }}$ (mean level change solely of the ablation area) for the single glaciers did not vary more than the $\Delta h_{\mathrm{m}}$ of the whole areas. It is true that this result could only hold good for time period in which the changes were all in the same direction and for glaciers not too different in length. It cannot be valid if $\Delta h$ has a turning point. As the ratios $\Delta h_{\mathrm{ma}} / \Delta h_{\mathrm{m}}$ do not vary much for the ten observed glaciers, the means $\Delta H_{\mathrm{ma}}$ (for the glacierized eastern Alps) must correlate with the mean net budget $b$ to the same degree as $\Delta H_{\mathrm{m}}$ itself does. As Ahlmann 
and Haefeli suggested, such a linear correlation should exist even for the amount of $\Delta h_{\mathrm{f}}$ solely for the firn line. It should be possible to find an empirical relation for a first approximation of $b$ deduced solely from $\Delta H_{\mathrm{ma}}$ or $\Delta H_{\mathrm{f}}$.

Besides the measurements of the mean level variations and hence of the volumetric changes, measurements of the ice velocity provide useful data for the glaciers' regime and its fluctuations.

When searching for a correlation between glacier variations and climatic fluctuations, it is most useful to extend such measurements to as many regions of the earth as possible. But repeating measurements in order to determine $\Delta h$ for a somewhat longer period-reaching back some decades - is possible today only in a few places. It is one of R. Finsterwalder's great merits that he mapped in an exact manner the glaciers of the mountain regions he visited during his expeditions and excursions. By his anticipation of the scientific recommendations of our day he has provided the present generation with some first surveys of whole glaciers or glacier tongues, which are now some $25 \mathrm{yr}$. old. These may now be used for measuring the changes. Besides the photogrammetric survey of the glacier state, he also in each case measured the ice velocities along transverse profiles.

In addition to his work in the eastern Alps Finsterwalder surveyed:

( I) In I928 Lednik Fedchenko with its affluents (Pamirs; north-west Tadzhikskaya Soviet Socialist Republic) (Finsterwalder, r932);

(2) In I 934 all the glaciers in the Nanga Parbat region (Punjab-Himalaya; then belonging to India) (Finsterwalder, r 938 );

(3) In I 937 some outlet glaciers of Jostedalsbreen in Norway, the largest glacierized area of continental Europe (Finsterwalder, I95 $\mathrm{I}[\mathrm{a}],[\mathrm{b}]$ ).

Meanwhile in all these regions his measurements have been repeated after 20 to 30 years:

(I) The surveys of 1928 were repeated in $195^{8}$ (I.G.Y.) by a Soviet-German expedition organized by the Uzbekskaya Akademiya Nauk (Regensburger, I963). The results will be published in the Freiburger Forschungshefte.

(2) The surveys of 1934 in the Nanga Parbat region were repeated

(a) for the Rakhiot Glacier, the most remarkable glacier on the northern side, in I 954 by Pillewizer (1956),

(b) for the six glaciers of the eastern and southern side in $195^{8}$ (I.G.Y.) by W. Kick and F. Loewe. For a preliminary report see Kick (1962; [Union Géodésique et Géophysique Internationale], I963, p. 96-98).

(3) The surveys of 1937 in southern Norway were repeated for Nigardsbreen by O. Liestøl and co-workers from the Norsk Polarinstitutt in Oslo, by mapping this outlet glacier at I : 20,000 with contour intervals of $20 \mathrm{~m}$. and including the whole drainage area, and especially surveying the lower part by photogrammetry every $2 \mathrm{yr}$. at I : 2,000 with $5 \mathrm{~m}$. contour lines, and by repeating the velocity profiles of I937 several times (personal communication from O. Liestøl). The tongue of Tunsbergdalsbreen, the second of the two most important glaciers surveyed in 1937, was resurveyed in $196 \mathrm{I}$ by E. Dorrer and the author.

Each of these re-surveys showed a recession of all these glaciers and thus showed the same trend as all Alpine glaciers. The study in detail of the differences in the extent of the recession in connection with the peculiarities of the climate concerned, the type of glacier, etc., may contribute to a better understanding of the required correlations.

\section{TunsBergdalsbreEn}

The ice cap known as Jostedalsbreen in the south-west of Norway covers some $815 \mathrm{~km} .^{2}$, of which about $473 \mathrm{~km}^{2}$ are still a connected area (Hoel and Werenskiold, ig62, p. 44). 
The largest of its 26 outlet glaciers and hanging glaciers is Tunsbergdalsbreen. From its origin in the flat ice cap it has a length of 17 to $18 \mathrm{~km}$., of which some $13 \mathrm{~km}$. concern the tongue alone (Fig. I). This tongue is on an average $\mathrm{I} \cdot 6 \mathrm{~km}$. broad. The accumulation area may only be estimated on the old $\mathrm{I}: 200$, 000 map to be some $33 \mathrm{~km} .^{2}$, the ablation area can be measured on the I : 25,000 map to be $2 \mathrm{r} \mathrm{km.}{ }^{2}$.

Though somewhat more difficult to reach than the neighbouring glaciers, it has attracted the interest of glacier research since very early times. Investigations had already begun in the years between 1868 and 1870 when Seue used this very glacier for his general studies of ice motion (Heim, I885, p. I43, I48, I 58, I66, I 70; Seue, I 870). Since then Norwegians, English-

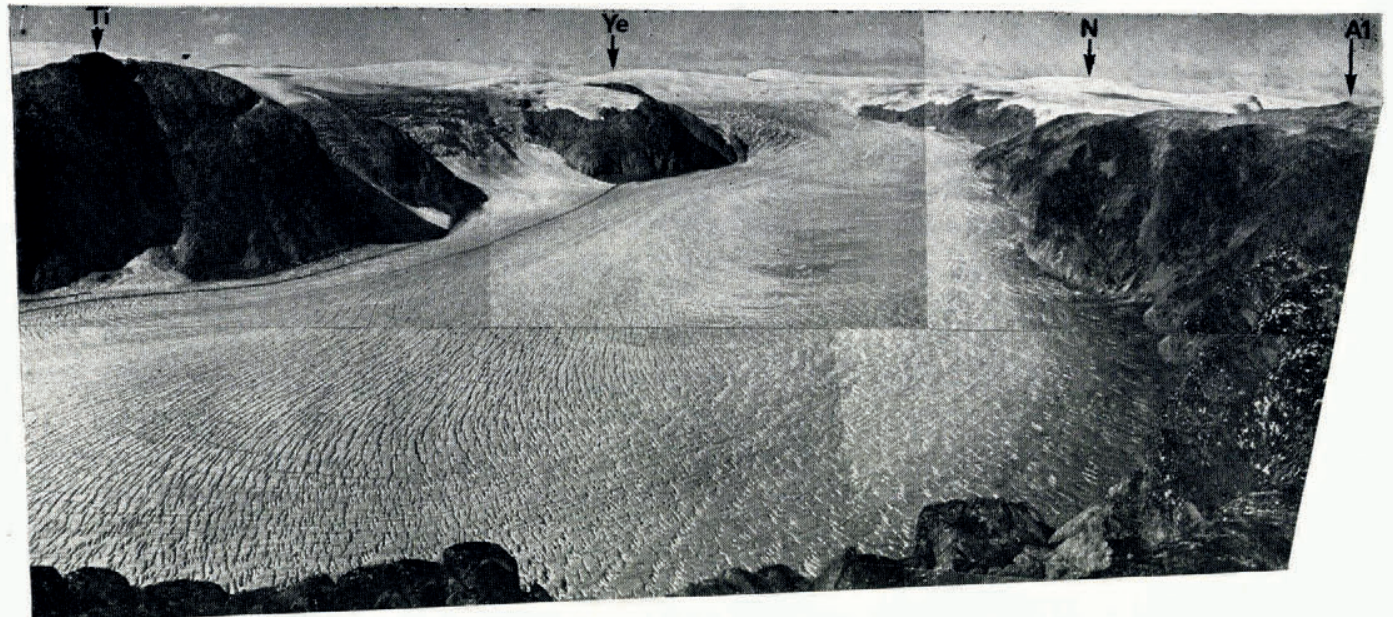

Fig. I. View of Tunsbergdalsbreen looking up-glacier from Brathay Group's "Windermere Cairn". Only $Y_{e}, A l$ and Ti are marked on the map. "Windermere Cairn" would be $2 \mathrm{~cm}$. right of the $\mathcal{N}$ of the north arrow, I4 mm. south of $19 \mathrm{~A}$ $(x=400,333 \cdot 4 ; y=57,909 \cdot 0 ; A=1,467.6 \mathrm{~m}$.) (Photopanorama by K. S. Maddever, $196 \mathrm{f})$

men, and Germans have done glaciological work at Tunsbergdalsbreen, a full bibliography of which is given by Hoel and Norvik ( 1962 ). Because of this work which is going on it seemed desirable to extend the existing map of the middle part of the tongue of Tunsbergdalsbreen drawn up after the survey of Finsterwalder in 1937 (Finsterwalder, I95 I [a], [b]; Pillewizer, I952) to the whole length of the tongue, and at the same time to measure the variations for the period I937-6r.

Referring to the variations in length of the Jostedalsbreen outlet glaciers, Fægri in his report [1950] stated: "The curves of the shorter ones are less regular with greater extremes in both directions. Those of the longer ones are more consistent, especially that of Tunsbergdalsbreen, the longest one, which has advanced once only since measurements were started in I 907 ". This statement made in 1948 can be extended up to the present day. In particular for the period here in question (I937-6I) each annual measurement resulted in a negative variation of the terminus (Liestøl, I963). This regular behaviour makes Tunsbergdalsbreen most appropriate for long-term variation studies.

\section{Mapping and Measuring the Variations of Tunsbergdalsbreen}

In 1937 Tunsbergdalsbreen, Nigardsbreen and some other smaller outlet glaciers of Jostedalsbreen were surveyed by terrestrial stereophotogrammetry. In r 938 the whole Jostedalsbreen was to be surveyed by aerial photogrammetry by order of Norges Geografiske 
Oppmåling. However the large firn area proved to be too uniformly white at that season to give the stereo-effect necessary for the photogrammetric evaluation. It would have been necessary to mark the firn area in a similar way as the firn fields of the Grosser Aletschgletscher were marked on the occasion of its aerial survey in i 957. Recently Norges Geografiske Oppmåling has made a new aerial survey of the whole Jostedalsbreen, the results of which are not yet published. The re-survey of Tunsbergdalsbreen by terrestrial photogrammetry was done from 25 July to I August I96r, whereas in 1937 it was from I3 July to r 8 July. The difference of I 3 days within the ablation season may on an average cause too large values of the rate $\Delta h$ of surface lowering. In the ablation area the error caused by neglecting this unknown effect is composed of the 13 days' ablation minus the vertical component $z$ of the ice motion (equation (2a)). As the mean daily ablation for the neighbouring Nigardsbreen at $75^{\circ}$ m.a.s.l. in July I 962 proved to be $10 \mathrm{~cm}$. (Østrem and Karlén, [1963], fig. I4, p. I82), the error is probably lower than $1 \mathrm{~m}$., and its neglect in relation to the measured surface variations of $-\mathrm{Io}$ to $-60 \mathrm{~m}$. for the $24 \mathrm{yr}$. is justified.

For the full technical details of the survey see Kick and Dorrer (1964) where the coordinates and further data for future field work are published; only a summary is given here. For the triangulation it was a great advantage that the English Brathay Exploration Group had set up a series of $2 \mathrm{~m}$. cairns well distributed round the glacier, which has saved us much field work. Dr. J. F. Nye, the adviser of the Group, will report on its glaciological work (see Appendix).

The accuracy of the very light phototheodolite TAF, giving the angles up to I centesimal minute, proved to be sufficient for the triangulation. The mean error for each of the triangulated points does not exceed $\pm \mathrm{I} \mathrm{m}$. within the local net of $\mathrm{I} 96 \mathrm{r}$. The position of this local net as a whole within the official survey net was found within $\pm 4 \mathrm{~m}$. The relative mean errors in the heights of the triangulated points lay between \pm 0.2 to $\pm 0.6 \mathrm{~m}$.; those of the absolute altitude came to about $\pm 0.6 \mathrm{~m}$.

In 196 I the four cairns of the two 1937 baselines could easily be found with the help of the foreground of the survey photographs of i 937 . By this the advantage of terrestrial photogrammetry for measuring variations could be fully used: use of the same stations and same bearings for the photographs essentially improves the accuracy in comparison with aerial photogrammetry. At Tunsbergdalsbreen as at Nanga Parbat the $24 \mathrm{yr}$. old cairns of Finsterwalder have "survived" very well.

The four photogrammetric baselines of I96I (Fig. 2) as well as the seven base lines of 1937 have been evaluated in 1963 at the Zeiss-Stereoautograph of the Institut für Photogrammetrie, Topographie und Allgemeine Kartographie of the Technische Hochschule München at I : 10,000 by E. Dorrer. The originals have been reduced to the scale of $1: 25,000$. The resulting map with the state of ice, snow and water in 1937 in blue, and with the state in $196 \mathrm{I}$ in red, is enclosed with this paper.

Unfortunately it is not possible to map the ice cap above the outlet glaciers by terrestrial photogrammetry, this ice cap not being towered over by rocks like the firn fields of the Alps. Moreover the forms of this old mountain range are not as well suited for terrestrial photogrammetry as those of the younger Alps. But had we had a few more days or better weather than in July I96I, it would easily have been possible to complete the survey of the tongue. At present some gaps still remain in the map. Nevertheless a study of the variations of the tongue remains possible.

Besides facilitating further glaciological work the purpose of the map is to represent the volumetric variations in a measurable manner. Furthermore the map should show the characteristic morphology of the side walls and the land below the terminus with various end moraines. P. J. Howarth (unpublished) has written a thesis trying to date these moraines by comparing them with those of the neighbouring Nigardsbreen of which the dates of formation are known from historical records. 
The mapped crevasses may give information about the stresses at the ice surface.

The method of measuring $\Delta h$ from the map is described in the next section on p. Io.

\section{The Variations}

The most striking variation is the disappearance of Brimkjelen Sjø, which in 1937 measured about $800 \mathrm{~m}$. in diameter and $0.48 \mathrm{~km} .{ }^{2}$ in area. Its depth was $99 \mathrm{~m}$. as can now be stated: in 1937 the water level was 858 m.a.s.l., and in $196 \mathrm{I}$ the dry bottom measured $759 \mathrm{~m}$. (red number on the map). 19.2 millions $\mathrm{m}^{3}$ of water had filled this lake. Already

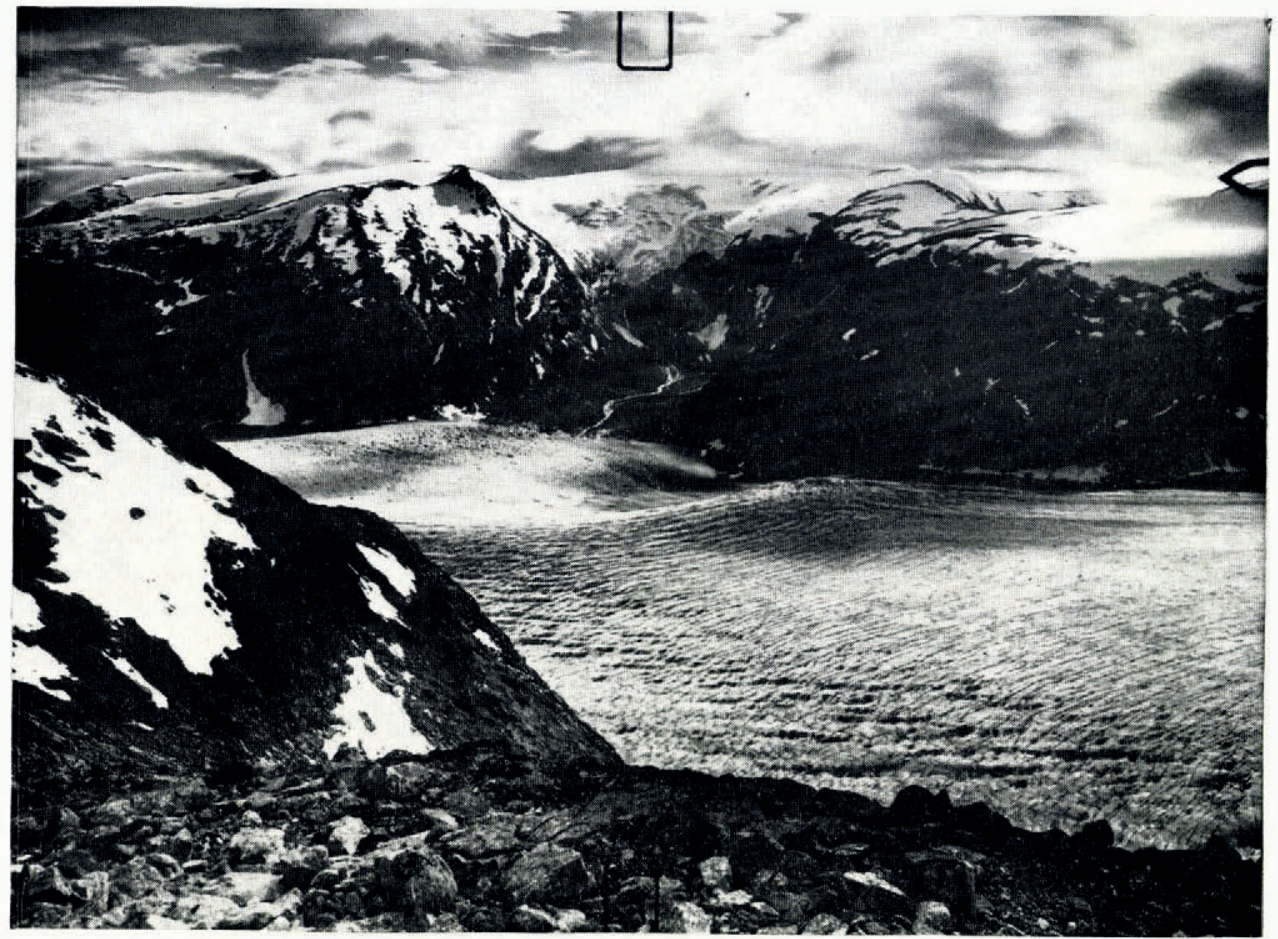

Fig. 2. Middle part of Tunsbergdalsbreen I96I. In 1937 the side valley beyond the main glacier held the lake Brimkjelen. Copy of a photogrammetric glass plate; original size $13 \times 18 \mathrm{~cm}$.; focal length $16,228 \mathrm{~cm}$. The one margin mark at the right side marks the horizon of the standpoint $(1573 \cdot 8 \mathrm{~m}$.). Photographed on 28 fuly $196 \mathrm{I}$ from the left standpoint of base line 20/I937 (20A on the map). The photographic axis is turned by $22^{\circ} 30^{\prime}$ left from the normal to the base line

between 1937 and $193^{8}$ the water surface had lowered considerably (Pillewizer, I 952). In I 949 the lake finally disappeared (personal communication from G. Østrem). When breaking through the damming ice, the waters of Brimkjelen Sjø will first be collected by the vast sandr-plain with the Tunsbergdals Vann (450 m.a.s.l.) and thus will not cause too much devastation. Literature on outbreaks of Brimkjelen Sjo, e.g. that of 6 August igoo, is listed in the bibliography of Norwegian glaciers (Hoel and Norvik, I962).

The variations of the location of the glacier snout are not represented on the map. They have been measured annually in relation to cairns by J. B. Rekstad, Oslo (1907-32), by Prof. K. Fægri, Bergen, and his assistants (1933-47), and (I948-6r) with local assistance on behalf of the Norsk Polarinstitutt. For the period I 937-6r , here in question, each of the annual measurements showed a recession. The sum of the single figures amounts to $430 \cdot 5 \mathrm{~m}$. Thus the length of the tongue decreased from $13.2 \mathrm{~km}$. in 1937 to $12.8 \mathrm{~km}$. in $196 \mathrm{r}$. Beginning with 
$1937 / 38$ the annual retreat in length in metres was: $10.5,19 \cdot 5,19,5,5,16,18,37,17,43$, 23, 54, 23, I $2 \cdot 5$, I 7, I 5 5, 20·5, I2, I0, 6, 一, 5, I 5, 27 (Fægri, [1950]; Liestøl, [1963] p. I 88).

The annual rates of $\Delta h_{\mathrm{t}}$ at the terminus - at present often almost equal to the net ablation, the velocity at the terminus being very small-could now be determined since

$$
\Delta h_{\mathrm{t}}=\Delta l(\tan \alpha-\tan \beta)
$$

where the slope $\alpha$ of the ice surface in its state in 1937 is documented by the map, and the slope $\beta$ of the bottom can now be measured in the field or taken from a new map surveyed by aerial photogrammetry in 1 : 50,000 in September 1964 by Widerøe, Norway (not yet published).

The loss $\Delta S$ in area for r $937-6$ i can only be estimated, the variations of the side margins being mapped only at some locations. For the margin at the terminus a plane-table sketch surveyed by the Brathay Exploration Group in 1957 has been used. Thus $\Delta S$ has been found to be about $\mathrm{I} \cdot 5 \times 1 \mathrm{IO}^{6} \mathrm{~m}^{2}$, that is 7 per cent of the ablation area.

A remarkable variation figure is given by Rogstad (I95I). In a hydrological study, using the varying ratio between the run-off in glacier rivers and the run-off in neighbouring rivers in the same general locality which are not fed by glaciers, for the period 1900-40 Rogstad computed an annual decrease of $0.4 \mathrm{~m}$. of water-equivalent for the whole glacier mass of Jostedalsbreen. In section 5 this figure will be compared with a roughly corresponding figure for the eastern Alps.

\section{The method and the results of determining $\Delta h$ r937-6I}

The horizontal shifts of the contour lines on the attached map contain the volumetric variation of Tunsbergdalsbreen from 1937 to 196 I. In the case of the eastern Alpine glaciers Finsterwalder used these shifts and, by assuming the new slope to be sufficiently parallel to the former slope of the zone between the corresponding contour lines, computed the mean height variation of the surface level for each $100 \mathrm{~m}$. zone, arising from the areas between the former and the new corresponding contour lines, measured by planimeter (Finsterwalder, 1954). This method is ideal for small variations occurring within a few years, but cannot be applied for such large variations as those of Tunsbergdalsbreen covering $24 \mathrm{yr}$. The assumption mentioned above is generally no longer valid, e.g. the former flat surface between the lines 875 and 900 in 1937 is in no way parallel to the steep descent of the ice fall between the same lines for $196 \mathrm{r}$.

Therefore three longitudinal profiles have been constructed from the map, each showing the state in 1937 and that in 1961 . One profile runs along the centre-line, the others some $400 \mathrm{~m}$. distant on the left and right side. The heights have been drawn with a ten times larger scale than the distances ( $1: 2,500$ cf. I : 25,000). The rates of the contour line shifts vary across the glacier in a sufficiently regular manner to justify their representation by these three longitudinal profiles. The vertical variations $\Delta h$ have been obtained from the profiles at every horizontal distance of $250 \mathrm{~m}$. The resulting three values for each transverse line have been averaged, giving the values along the centre-line double weight, as they represent a larger area. Finally the mean $\Delta h$ for each Ioo $\mathrm{m}$. altitude zone has been determined.

The values of $\Delta h$ for the surveyed region between the altitudes 800 and $\mathrm{r}, 600 \mathrm{~m}$. form a remarkably regular, almost linear curve when plotted against altitude with a gradient of $\Delta h \mid \Delta A=-0 \cdot 053 / 24 \mathrm{yr} .=-0 \cdot 0022 / \mathrm{yr}$. (Fig. 3, Table II). Near the terminus the amount of shrinking is certainly more than $60 \mathrm{~m}$. or more than $2.5 \mathrm{~m} . / \mathrm{yr}$. Up-glacier it decreases. At the firn line near $\mathrm{I}, 500 \mathrm{~m}$. it still reaches some I I m. $/ 24 \mathrm{yr}$. or $0.46 \mathrm{~m}$. $/ \mathrm{yr}$. Owing to the reasons mentioned the variations of the ice cap in the accumulation area could not be measured, but the surveyed area reaches well up to the rim of the ice cap and the longitudinal profile provides the (negative) gradient of $\Delta h$ at that location. Thus it can be deduced that for $1937-6 \mathrm{r}$ the surface of the ice cap dropped less than $0 \cdot 4 \mathrm{~m}$./yr. As Rogstad's value of $0.4 \mathrm{~m}$./yr. refers to the whole glacier mass, the ice cap alone had also for $1900-40$ shrunk much 
less than $0.4 \mathrm{~m}$. $/ \mathrm{yr}$., as the rate $\Delta h_{\mathrm{mc}}$ solely for the accumulation area generally is smaller than half the rate $\Delta h_{\mathrm{m}}$ for the whole glacier. For seven east Alpine glaciers the average ratio $\Delta h_{\mathrm{mc}} / \Delta h_{\mathrm{m}}$ was $0 \cdot 47$, whilst the ratio $\Delta h_{\mathrm{ma}} / \Delta h_{\mathrm{m}}$ for the ablation areas was $\mathrm{I} \cdot 83$ (these figures computed from Finsterwalder's data (I953)).

In some rather rare cases the lines of equal surface lowering $\Delta h$ form ellipses on the map with their long axes approximately parallel to the general direction of flow. More often these isolines are drawn apart again in the direction of flow. Corresponding to this distribution of isolines a graph of $\Delta h$ values along the centre-line or lines parallel to it form waves, but these

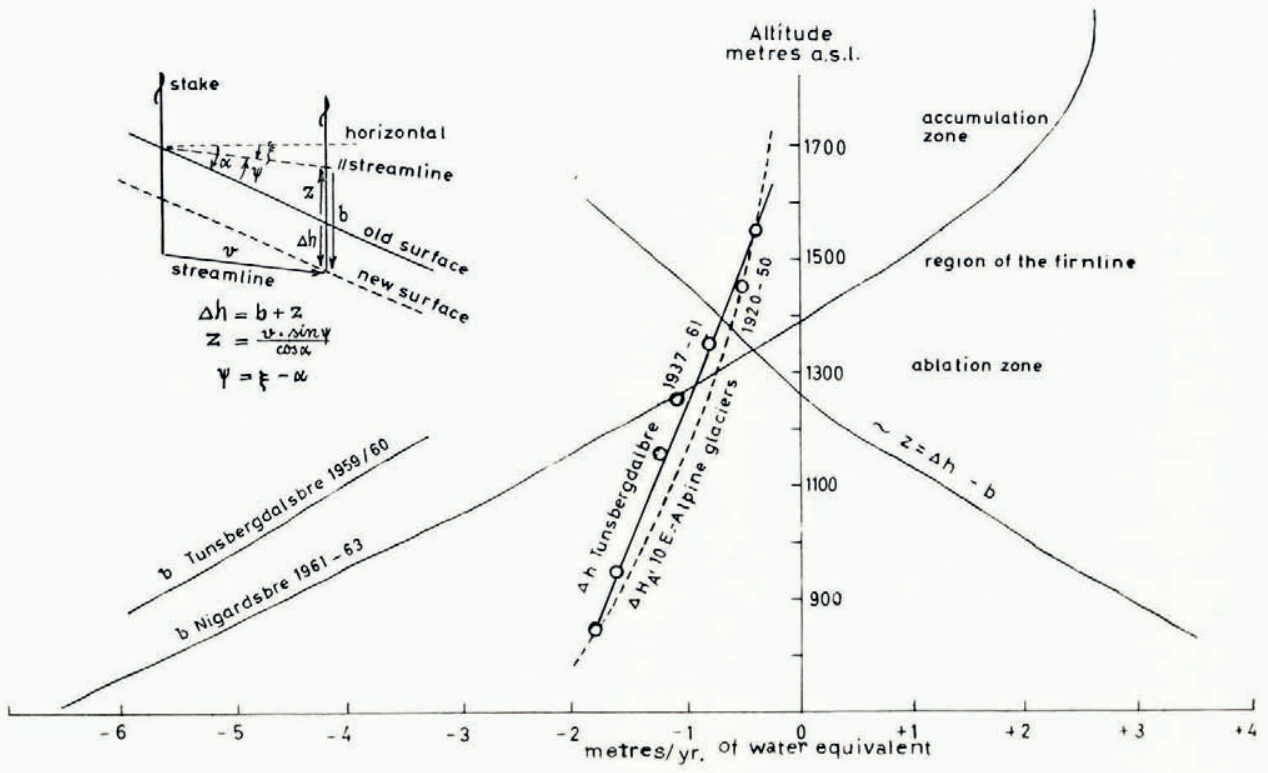

Fig. 3. Four quantities as functions of the altitude:

(I) The geodetically measured surface-level variation $\Delta h$ at Tunsbergdalsbreen, period I937-6I.

(2) Its comparison with $\Delta H_{A^{\prime}}$, the mean for ten east Alpine glaciers, period 1920-50; the latter curve (Finsterwalder, 1953 , fig. 4) is shifted by the altitude difference of $I, 350 \mathrm{~m}$., by which the firn line in the Alps is higher.

(3) Configuration of the net budget curve $b: b$ Tunsbergdalsbre 1959-6o (Maddever 196I); $b$ Nigardsbre 1961-63 (0strem and Karlén, $1963 ;$ Ostrem and Liestol, $1964[b])$.

(4) The vertical component $z=\Delta h-b$ of the ice motion. As data from different glaciers are used this curve is realistic in its general shape only.

waves are smooth and with only small amplitude. For successive horizontal distances of $250 \mathrm{~m}$. along the centre-line up the glacier starting at $800 \mathrm{~m}$.a.s.l. the following negative values of $\Delta h$ in metres were found in $196 \mathrm{r}$ :

$59,53,5 \mathrm{O}, 45,40,36,44,42,42,36,4 \mathrm{I}, 44,4 \mathrm{I}, 36, \ldots$, and upwards from $\mathrm{I}, \mathrm{I} 00 \mathrm{~m}$. :

$34,33,33,32,3$ I $32,33,32,3$ I, 30, 29, 26, 25, I9, I9, I 5, I3, I I, 9, 9, . .

The averaging of the three values at a given transverse line makes these waves disappear. The series of these means each representing a large part of the glacier breadth, form the aforementioned almost linear curve (Fig. 3).

Furthermore the map shows that the lower of the two side glaciers at the right, the one above the former lake Brimkjelen, lost some $50 \mathrm{~m} . / 24 \mathrm{yr}$. between altitudes of about 900 and $\mathrm{I}, \mathrm{I}$, $\mathrm{m}$., and the upper one some $25 \mathrm{~m}$. at between altitudes I,200 to I, $300 \mathrm{~m}$. Thus the losses are of the same order of magnitude as those of the trunk stream at the same altitudes. The rates of the surface lowering have been rather similar for the same altitudes all over the Tunsbergdal 
region. Quite obviously they depend on the altitude above sea-level or on the altitude distance from the firn line.

The amounts of $\Delta h$ measured for the period 1937-6I would be of less use if within the $24 \mathrm{yr}$. the trend had changed from decreasing to increasing. Then the period would have been too long to interpret the variations. But in the case of Tunsbergdalsbreen we know from the annual measurements of the variations in length that the period was one of continuous recession and that turning points did not happen.

For the tongue the variation of the volume has been computed for each mapped I $00 \mathrm{~m}$. height zone, and estimated for the unmapped zones according to

$$
\Delta V=\Sigma \Delta V_{A}=\Sigma S_{A 1961} \Delta h_{A}+\Sigma \Delta S_{A} \frac{\Delta h_{A}}{2} .
$$

The result was a loss of $787 \times 10^{6} \mathrm{~m} .{ }^{3}$ of ice in the course of $24 \mathrm{yr}$., or an average annual loss of $30 \times 10^{6} \mathrm{~m} .^{3}$ of water, or, for comparison, in every year $\mathrm{I} \cdot 6$ times the amount of water in Brimkjelen Sjø in its state of 1937 . These annual water masses of the glacier retreat fed the draining Tunsberg Elv in addition to the annual precipitation.

The mean surface lowering of the ablation zone alone has been computed from

$$
\Delta h_{\mathrm{ma}}=\frac{\sum S_{A} \cdot \Delta h_{A}}{S_{\mathrm{a}}}=\frac{748 \times \mathrm{IO}^{6} \mathrm{~m} .^{3}}{\mathrm{I} 9 \cdot 6 \times \mathrm{IO}^{6} \mathrm{~m}^{2}}=-38 \cdot 2 \mathrm{~m} .
$$

the average shrinking for one year being $-\mathrm{I} \cdot 45 \mathrm{~m}$. of water-equivalent.

\section{Comparison of the Variations with those of Alpine Glaciers}

The gradient of the altitude variation of $\Delta h$ at the ablation area

The previously mentioned nearly linear function, valid for the ablation area, may be given as

$$
\Delta h_{A}=\Delta h_{0}+k \Delta A
$$

where $\Delta h_{A}$ is the surface-level variation at the altitude $A$ and $\Delta A=A-A_{0}$ where $A_{\mathrm{o}}$ is a datum altitude.

If we use the firn line, as this datum altitude $A_{0}$ (for this purpose the difference from the equilibrium line is unimportant), we may compare the result for Tunsbergdalsbreen, period I937-6I, with that for the eastern Alps averaged for ten glaciers, unfortunately at present available for the period $1920-50$ only:

$$
\left.\begin{array}{rl}
\text { Tunsbergdalsbreen } & \Delta h_{A}=-0.46+0.0022 \Delta A \mathrm{~m} . / \mathrm{yr} . \text { of ice } \\
\text { Eastern Alps } \quad \Delta h_{A}=-0.53+0.002 \mathrm{I} \Delta A \mathrm{~m} . / \mathrm{yr} \text {. of ice }
\end{array}\right\}
$$

where the firn line of Tunsbergdalsbreen is supposed to be near I,500 $\mathrm{m}$. and that of the east Alpine glaciers near 2,850 m. The equation (4a) referring to the eastern Alps is a linearization of Finsterwalder's parabola (Finsterwalder, I953, fig. 4) and is a good approximation for a range of some $700 \mathrm{~m}$. in altitude (from 2,200 to 2,900 m.a.s.l.), for which it is compared with the results of Tunsbergdalsbreen (from 850 to $\mathrm{I}, 55^{\circ}$ m.a.s.l.). For a larger extension Finsterwalder (1953, p. 2 Io and fig. 4) found the parabola

$$
\Delta h_{A}=\Delta h_{0}-\mathrm{o} \cdot \mathrm{or} 2\left(A-345^{\mathrm{o}}\right)^{2} \mathrm{~m} . / \mathrm{yr} \text {. of ice }
$$

where the datum altitude is located by some $600 \mathrm{~m}$. above the equilibrium line.

The comparison of equations (4a) shows that the gradient of the altitude variation of $\Delta h$ in the ablation area is very nearly the same in the Alps as for the large and representative Tunsbergdalsbreen in Norway. Probably this conformity is primarily caused by a uniform regularity in the altitude variation of the ablation on which Haefeli has published an important paper (1962). 
The mean surface-level variations

Some earlier data

As mentioned in section 4, for the period i 900-40 Jostedalsbreen, which includes Tunsbergdalsbreen, had decreased on an average by $0.4 \mathrm{~m}$. of water equivalent annually (Rogstad, I95I). This value agrees well with the data for the eastern Alps which Finsterwalder gives: For 1890 to $1920-0.30 \mathrm{~m}$. $/ \mathrm{yr}$. and for 1920 to $1950-0.61 \mathrm{~m} . / \mathrm{yr}$. of ice (Finsterwalder, I953; I96 I, p. 326); thus for Rogstad's time period I900-40 Finsterwalder reports nearly the same rate, namely $-0.45 \mathrm{~m}$./yr. of water equivalent. Though it is not quite correct to interpolate such an average value, the result at least proves a parallel trend apparently of the same order of magnitude. For the western Alps some data for the Grosser Aletschgletscher seem to confirm that large single glaciers with rather regular forms, or the average of several typical glaciers, are apparently responding to the same climatic trends by similar mean surface-level variation $\Delta h_{\mathrm{m}}$ or similar values of net budget $b$ (equation (3a)). At a point near the firn line, and therefore at a representative location of the Grosser Aletschgletscher, the lowering of the surface from I 85 I to 1947 amounted to $0.54 \mathrm{~m}$./yr. of ice (Haefeli, I955-56, p. 9). Now exact mapping has provided the average rate of shrinking of the whole Aletsch surface for the period I 926 to 1957 as $0.53 \mathrm{~m}$./yr. of ice (Kasser, I96I, p. $22 \mathrm{I}$ ), a value very near to the corresponding figure for the means for the eastern Alps $(0.50 \mathrm{~m}$. $/ \mathrm{yr}$. of ice as interpolated from $0 \cdot 6$ I for $1920-50$ and 0.13 for $\left.195^{\circ}-59\right)$.

Comparison of the results from Tunsbergdalsbreen $1937-6 I$ with the data from Alpine glaciers and Werenskioldbreen, Vestspitsbergen

The value of $\Delta H_{\text {ma }}$ solely for the ablation areas, averaged for eight typical glaciers of the eastern Alps for the period I $920-50$ is $-\mathrm{I} \cdot \mathrm{I} 2 \mathrm{~m}$. $/ \mathrm{yr}$. $\pm 0 \cdot 07 \mathrm{~m}$. $/ \mathrm{yr}$. of ice (computed from the data in Finsterwalder (I953)). The amount of $\Delta H_{\mathrm{m}}$ for the whole glacier areas decreased from $-0.6 \mathrm{I} \mathrm{m}$./yr. for $\mathrm{I}_{920}-50$ to $-0 . \mathrm{I} 3 \mathrm{~m}$./yr. for $1950-59$ (Finsterwalder, I96 I, p. 33 I), though an assistant of Finsterwalder has recently told me that a new computation would come to a loss of more than $0.13 \mathrm{~m}$. $/ \mathrm{yr}$. Thus in reality the amount of the $\Delta H_{\mathrm{m}}$ for $1937-59$ would be something larger than the result of the interpolation $\frac{\mathrm{I} 3 \times 0 \cdot 6 \mathrm{I}+9 \times 0 \cdot \mathrm{I}_{3}}{22}=-0 \cdot 4 \mathrm{I} \mathrm{m} . / \mathrm{yr}$. of ice or $-0.37 \mathrm{~m} . / \mathrm{yr}$. of water-equivalent. By assuming for $1937-59$ the same ratio $\Delta H_{\mathrm{ma}} / \Delta H_{\mathrm{m}}$ as that computed for $\mathrm{I}_{920-50}$, namely $\mathrm{I} \cdot 84$, we find $\Delta H_{\mathrm{ma}}=-0.75 \mathrm{~m} \cdot / \mathrm{yr}$. of ice, or $-0.68 \mathrm{~m} . / \mathrm{yr}$. of water for the period $1937-59$, which covers 92 per cent of the interval I937-6 1 to which the measurements at Tunsbergdalsbreen refer.

As the rate of the local $\Delta h$ is a function of the altitude, the mean $\Delta h_{\text {ma }}$ for the ablation area also depends on the altitude extension of this area. Therefore the only figures of $\Delta h_{\mathrm{a}}$ which are comparable, are those which belong either to glacier tongues of a similar vertical extension or to corresponding altitude zones counted from the firn line. The values of $\Delta H_{\mathrm{ma}}$ used above for the Alpine glaciers on the average refer to six roo $\mathrm{m}$. zones below the equilibrium line. If we confine $\Delta h_{(\mathrm{ma})}$ for Tunsbergdalsbreen also to the first six roo $\mathrm{m}$. zones below its firn line, i.e. from $\mathrm{I}, 500$ to $900 \mathrm{~m}$., its value naturally gets smaller, namely $-\mathrm{I} \cdot 26 \mathrm{~m}$. $/ \mathrm{yr}$. of ice, or $-\mathrm{I} \cdot \mathrm{I} 5 \mathrm{~m}$./yr. of water.

There is still a simpler substitution of the $\Delta h_{\mathrm{m}}$ of the whole glacier area: Ahlmann (1948, p. $5^{6}$ ) and Haefeli ( $1955^{-56}$, p. 9) suggest the use of the $\Delta h_{\mathrm{f}}$ at the firn line as a representative figure for the whole glacier variation. For Tunsbergdalsbreen this height variation, for the region near I, $500 \mathrm{~m}$., amounts to $-\mathrm{I} 2 \mathrm{~m}$. for $\mathrm{I} 937-6 \mathrm{I}$, or $-0.50 \mathrm{~m}$./yr. of ice, or $-0 \cdot 45$ $\mathrm{m}$./yr. of water. For eight east Alpine glaciers for $1920-50 \Delta H_{\mathrm{f}}$ was $-0.53 \mathrm{~m}$./yr.; for the period ${ }_{1} 937^{-59}$ it may be deduced in the same manner as for $\Delta H_{\mathrm{m}}$ to be $-0 \cdot 36 \mathrm{~m}$./ $\mathrm{yr}$. of ice or $-0.33 \mathrm{~m} . / \mathrm{yr}$. of water.

For Werenskioldbreen in Vestspitsbergen the height variation at the firn line (near 
$300 \mathrm{~m}$.a.s.l.) was about $-\mathrm{I} \cdot 45 \mathrm{~m}$./yr. of ice or $-\mathrm{I} \cdot 3^{2} \mathrm{~m}$./yr. of water for the period $\mathrm{I} 93^{6}-5^{8}$, covering 88 per cent of the measuring period for Tunsbergdalsbreen (Kosiba, ig6o, table II, p. I 7).

Table I. Mean Variations of Surface Levels in m./Yr. of Water-equivalent

\begin{tabular}{|c|c|c|c|c|c|}
\hline Region & Latitude & $\begin{array}{l}\text { Altitude } \\
\text { equilibrium }\end{array}$ & $\begin{array}{l}\Delta h_{\mathrm{f}} \\
\text { or firn line }\end{array}$ & $\Delta h_{(\mathrm{ma})} *$ & $\begin{array}{l}\Delta h_{\mathrm{m}} \text { for } \\
\text { the whole } \\
\text { glacier }\end{array}$ \\
\hline $\begin{array}{l}\text { Eastern Alps I } 937-59 \\
\text { Tunsbergdalsbreen 1937-61 } \\
\text { Werenskioldbreen } 1936-{ }^{8}\end{array}$ & $\begin{array}{l}47^{\circ} \mathrm{N} \\
6 \mathrm{o} \cdot 6^{\circ} \mathrm{N} \\
77^{\circ} \mathrm{N}\end{array}$ & $\begin{array}{c}2,850 \\
1,500 \\
300\end{array}$ & $\begin{array}{l}-0 \cdot 33 \\
-0 \cdot 46 \\
-I \cdot 32\end{array}$ & $\begin{array}{l}-0.68 \\
-\mathrm{I} \cdot \mathrm{I} 5\end{array}$ & -0.37 \\
\hline
\end{tabular}
$* \Delta h_{(\mathrm{ma})}$ is the mean height variation for the first six $100 \mathrm{~m}$. zones below the equilibrium or
firn line.

For Tunsbergdalsbreen the deficit or negative budget $-\Delta h$ of the mass balance on the one hand and the ice motion on the other was $1 \cdot 7$ times larger than that of the east Alpine glaciers, as given by $\Delta h_{(\mathrm{ma})}$, or $\mathrm{I} \cdot 4$ times as given by $\Delta h_{\mathrm{f}}$. The corresponding value for Werenskioldbreen is again more than twice as large as that of Tunsbergdalsbreen. These comparisons partly need more detailed investigation during single budget years, and partly further investigation of longer-term variations so that short period influences cannot hide an overall large-scale correlation.

\section{The Numerical Relations Between Altitude, $\Delta h, b$ and $z$}

Table II and Figure 3 show the geodetically measured rates of the surface lowering $\Delta h$ related to the corresponding altitudes of Tunsbergdalsbreen. As previously mentioned $\Delta h$ is a balance figure, resulting from the two counter motions $b$ and $z$. As all these elements are functions of the altitude, they may be compared in a diagram (Fig. 3) referred to the altitudes. Unfortunately this cannot be done with values for Tunsbergdalsbreen itself and not for the same period. But the available figures of the net budget curve for the neighbouring Nigardsbreen averaged for the two budget years 1961-63 (Østrem and Karlén, [1963]; Østrem and Liestøl, I964[a], p. 5) seem to be plausible rates and not extreme values. At least the configuration of the curve may be confirmed by the values of $b$ for Tunsbergdalsbreen in $1959 / 60$ (Maddever, unpublished) in Figure 3. Hence the differences $\Delta h-b$ provide a possible curve, likely to be at least of the right average slope, for the altitude variations of the vertical components $z$ of the annual ice motion (equation (2a) with the mentioned assumptions).

Table II. Variation of Height Changes, Budget and Vertical Movement with Altitude

\begin{tabular}{|c|c|c|c|c|c|}
\hline \multicolumn{2}{|c|}{$\begin{array}{c}\text { Tunsbergdalsbreen } \\
\quad 1937-6 \mathrm{I}\end{array}$} & \multicolumn{2}{|c|}{$\begin{array}{l}\text { Ten east Alpine glaciers } \\
1920-50\end{array}$} & $\begin{array}{c}\text { Nigardsbreen } \\
\text { I } 961-63\end{array}$ & $\begin{array}{l}\text { Deduced vertical } \\
\text { movement }\end{array}$ \\
\hline Altitude & $\Delta h_{A}$ & $\Delta h_{A}$ & Altitude & $b$ & $z$ \\
\hline m.a.s.l. & \multicolumn{2}{|c|}{$\mathrm{m} . / \mathrm{yr}$. of water } & m.a.s.l. & \multicolumn{2}{|c|}{$\mathrm{m} . / \mathrm{yr}$. of water } \\
\hline $\begin{array}{l}\text { terminus: } \\
500(1937) \\
500-700 \\
700-800\end{array}$ & $\begin{array}{l}\text { not measured } \\
\text { not measured } \\
\text { not measured }\end{array}$ & & & $-6 \cdot 1$ & \\
\hline $800-900$ & $-1 \cdot 82$ & $-\mathrm{I} \cdot 8 \mathrm{I}$ & 2200 & $-5 \cdot 1$ & $+3 \cdot 28$ \\
\hline $900-1000$ & $-\mathbf{I} \cdot 63$ & $-\mathrm{I} \cdot 54$ & 2300 & $-4 \cdot 05$ & $+2 \cdot 4^{2}$ \\
\hline $1000-1100$ & not measured & $-1 \cdot 30$ & 2400 & $-3 \cdot 0$ & \\
\hline $1100-1200$ & $-1 \cdot 25$ & $-1 \cdot 08$ & 2500 & -2.05 & $+o \cdot 80$ \\
\hline $1200-1300$ & $-1 \cdot 13$ & -0.88 & 2600 & $-1 \cdot 15$ & +0.02 \\
\hline $1300-1400$ & -0.82 & $-0 \cdot 70$ & 2700 & -0.3 & $-0.5^{2}$ \\
\hline $1400-1500$ & -0.53 & -0.55 & 2800 & +0.48 & $-\mathrm{I} \cdot \mathrm{OI}$ \\
\hline $1500-1600$ & $-0 \cdot 3^{8}$ & $-0 \cdot 4^{2}$ & 2900 & $+\mathrm{I} \cdot 3$ & $-\mathrm{I} \cdot 68$ \\
\hline $1600-1700$ & not measured & $-0 \cdot 3^{2}$ & 3000 & $+1 \cdot 95$ & \\
\hline I $700-1800$ & not measured & & & $+2 \cdot 4$ & \\
\hline
\end{tabular}


The "ablation gradient" $a=\Delta A / \Delta H$ of Haefeli (I962) is, in the terms and symbols of this paper, the net budget gradient $\Delta b / \Delta A$. For Nigardsbreen, the glacier near to Tunsbergdalsbreen, the average of this gradient for two budget years was $+0 \cdot 0085$ (Table II), whereas the figures for the Grosser Aletschgletscher and of two American glaciers (lat. $46^{\circ}$ to $47^{\circ} \mathrm{N}$.), cited by Haefeli (1962, p. 52) are $+0 \cdot 0099$, and $+0 \cdot 0108$ respectively.

The marginal sketch in Figure 3 shows that the vertical component of the ice movement is

$$
z=\frac{v \sin \psi}{\cos \alpha} \text {. }
$$

For a sufficiently flat surface slope

$$
z=v \sin \psi,
$$

where $v$ is the scalar magnitude of the velocity vector of a particle of ice $(\mathrm{m} . / \mathrm{yr}),. \psi$ is the angle of the velocity vector measured from the surface slope (Kriechwinkel $\beta$ in Haefeli (1955-56), p. 5) so that

$$
\psi=\xi-\alpha
$$

where $\xi$ is the slope of the velocity vector measured from the horizontal and $\alpha$ is the slope of the surface.

For the ablation area the net budget $b$ is negative and increasing with decreasing altitude or with increasing distance $x$ from the firn line. Therefore according to (2a) the vertical component $z$ of the ice movement must be positive and must increase with increasing distance from the firn line. By differentiating equation $(5 a)$ the gradient of $z$ is given by

$$
d z / d x=v \cos \psi d \psi / d x+\sin \psi d v / d x
$$

where $d v / d x=\dot{\epsilon}$, the strain-rate.

All quantities in this equation are measurable and thus could be checked along a longitudinal profile by combining geodetic and stake measurements. The velocities $v$ for one year observation periods and the strain-rates have already been measured at Tunsbergdalsbreen by the Brathay Group since $1957 / 5^{8}$. At the tongue $v$ ranged between 73 and $\mathrm{I} 53 \mathrm{~m}$. $/ \mathrm{yr}$. for $1959 / 60$ and the strain-rate for $1957-60$ between o and $-0.030 \mathrm{yr}^{-1}$ with increasing negative rate (compression) towards the terminus. For a large part of the longitudinal profile $d z / d x \approx \sin \alpha \Delta z / \Delta A=0.008 \mathrm{I} \times 0.05 \mathrm{I}=0.0004 \mathrm{I} \mathrm{yr}^{-1}$.

For laminar flow the velocity vector is nearly parallel to the bottom slope $\beta$, so

$$
\xi=\beta \text {. }
$$

The equations $(5 \mathrm{a}),(6),(7)$ provide important relations for a mathematical description of the surface longitudinal profile, but the configuration given by them varies with time due to the kinematic waves continuously running down-glacier.

\section{The Transverse Velocity Profile ig37 and i96i}

The method of measuring the ice velocity by terrestrial photogrammetry has been briefly described in this fournal (Finsterwalder, I 954). Its advantage consists in providing quite a lot of data and in giving the opportunity for checking all results afterwards and for measuring additional data from the photographs at any later time.

In ${ }_{196} \mathrm{I}$ we did not succeed in finding exactly the same location again; the cairns of the two stations probably having been destroyed by avalanches. We therefore measured as near to the 1937 profile as we could estimate. Subsequent evaluation of the field work showed that the profile of $196 \mathrm{I}$ was situated $50 \mathrm{~m}$. further down glacier. The surface slope of the $196 \mathrm{I}$ profile was Io per cent steeper than that of the I937 profile $\left(\alpha_{1937}=0 \cdot 09 \mathrm{I}\right)$.

The ice thickness at the location of the profiles changed on an average by $\Delta h=-45 \mathrm{~m}$./ $24 \mathrm{yr}$. An estimate of the thickness $h$ itself might be attempted by using the following relation: 
The ice discharge $q$ through the vertical cross-section of the profile must be the same as the discharge through the surface $S_{\mathrm{t}}$ between the profile and the terminus

$$
q=S_{\mathrm{t}} z_{\mathrm{t}} .
$$

The area of the cross-section is

$$
A=q / v
$$

where $v$ is the annual movement averaged for the vertical area $A$. Then the average thickness is

$$
h=A / w
$$

where $w$ is the width.

The available data, however, are not adequate. Estimated figures for the average annual budget and for the annual flow velocity over the cross-section are not reliable enough to yield a meaningful value for the thickness.

The maximum of the temporary velocity, near the centre-line, had decreased from $34 \mathrm{~cm}$./day in 1937 (13/14 July) to $23 \mathrm{~cm}$./day in I96I (29/3I July) that is by 32 per cent. The Brathay Group measured at about the same location an annual velocity of $\mathrm{I} 20 \mathrm{~m}$. for I $959 / 6$ o or $33 \mathrm{~cm}$./day. The average value for the whole transverse profile (area of the velocity profile divided by the breadth) decreased from $24.5 \mathrm{~cm}$./day in 1937 to $17.0 \mathrm{~cm}$./day in $196 \mathrm{I}$, that is by $3 \mathrm{I}$ per cent.

The weather at the time of the survey in 1937 was outstandingly good. More melt water may have been running than in I96I when we had particularly cloudy and rainy weather. Normally the rain water does not reach anywhere near the quantity of melt water on sunny days. More water penetrating to the glacier bed may have had an increasing effect on the velocity in 1937 .

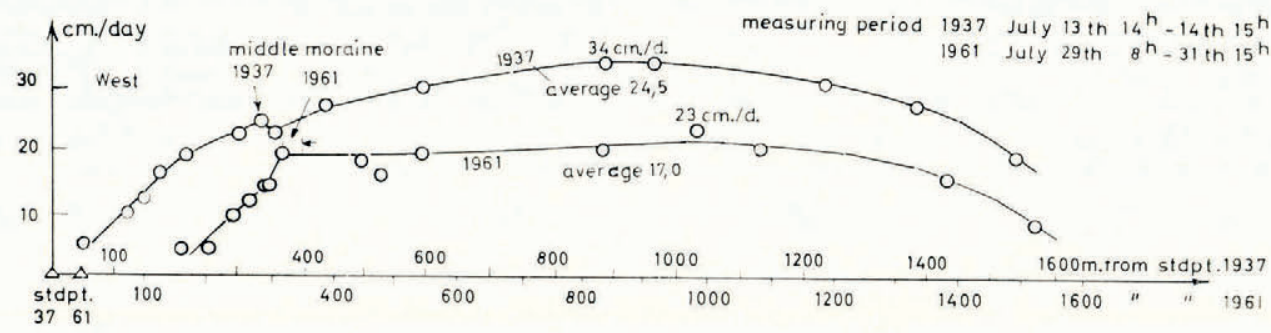

Fig. 4. Temporary velocity transverse profile 1937 and $196 \mathrm{I}$. Scale of the daily movement is I, ooo times the scale of the glacier breadth or of the distance from the fixed points. Even neglecting the particular velocity value at the middle moraine, the configuration of the 1961 curve towards the western border had changed to that of a Blockschollen movement

The velocity profile of 1937 for Tunsbergdalsbreen has become a prototype for a streaming glacier. The variation of the velocity rates along the transverse line has had the distinct parabolic form as in the case of viscous liquids, typical for slowly flowing valley glaciers (Pillewizer, I950, I952). On the left half of the glacier the velocity curve remained in this same configuration in I96r. But on the right side (left in Fig. 4) the form had changed and had become that of a glacier with Blockschollen-movement. For this mode of flow the gradient of the velocity at a small margin zone is very great whereas the largest part of the profile is moving as a solid unit. This change in the profile form from 1937 to 1961 is the more remarkable as the velocity had decreased by $3^{1}$ per cent. Obviously the two modes of flow do not only depend on the amount of the velocity nor only on the relation of the velocity to the breadth. Stress conditions caused by other reasons also influence the mode of flow.

\section{MS. received 31 December ${ }_{196} 6$}


REFERENCES

Ahlmann, H. W. 1948. Glaciological research on the North Atlantic coasts. London, Royal Geographical Society. (R.G.S. Research Series, No. I.)

Brathay Exploration Group. 1957-63. Annual reports and account of expeditions. Brathay Hall, Ambleside, Westmorland, Brathay Exploration Group.

Fægri, K. [1950.] On the variations of western Norwegian glaciers during the last 200 years. Union Géodésique et Géophysique Internationale. Association Internationale d'Hydrologie Scientifique. Assemblée générale d'Oslo, 19-28 aoât 1948. Procès-verbaux des séances. Tom. 2, p. 293-303.

Finsterwalder, R. 1932. Geodätische, topographische und glazialologische Ergebnisse der Alai Pamir Expedition 1928. Berlin, Verlag D. Reimer. 2 vols.

Finsterwalder, R. 1938. Die geodätischen, gletscherkundlichen und geographischen Ergebnisse der Deutschen Himalaya Expedition 1934 zum Nanga Parbat. Berlin, Karl Siegismund Verlag.

Finsterwalder, R. $195 \mathrm{I}$ [a]. Erd- und Luftphotogrammetrie im Gebirge. Allgemeine Vermessungs-Nachrichten, Jahrg. 58 , Ht. 3 , p. $53^{-6}$. [With 2 maps.]

Finsterwalder, R. I 95 I [b]. The glaciers of Jostedalsbreen. Journal of Glaciology, Vol. I, No. Io, p. $557-58$.

Finsterwalder, R. I 953. Die zahlenmässige Erfassung des Gletscherrückgangs an Ostalpengletschern. Zeitschrift für Gletscherkunde und Glazialgeologie, Bd. 2, Ht. 2, p. 189-239.

Finsterwalder, R. 1954. Photogrammetry and glacier research with special reference to glacier retreat in the Eastern Alps. Fournal of Glaciology, Vol. 2, No. I5, p. 306-1 5 .

Finsterwalder, R. I961. On the measurement of glacier fluctuations. Union Géodésique et Géophysique Internationale. Association Internationale d'Hydrologie Scientifique. Assemblée générale de Helsinki, 25-7-6-8 196o. Commission des Neiges et Glaces, p. 325-34.

Haefeli, R. 1955-56. Gletscherschwankung und Gletscherbewegung. Schweizerische Bauzeitung, Jahrg. 73, Ht. 42, p. 626-31; Ht. 44, p. 693-97; Jahrg. 74, Ht. 44, p. 667-69.

Haefeli, R. 1962. The ablation gradient and the retreat of a glacier tongue. Union Géodésique et Géophysique Internationale. Association Internationale d'Hydrologie Scientifique. Commission des Neiges et Glaces. Colloque d'Obergurgl, IO- - I $^{3}-9$ I962, p. 49-59.

Heim, A. 1885. Handbuch der Gletscherkunde. Stuttgart, J. Engelhorn.

Hoel, A., and Norvik, J. 1962. Glaciological bibliography of Norway. Norsk Polarinstitutt. Skrifter, Nr. I26.

Hoel, A., and Werenskiold, W. 1962 . Glaciers and snowfields in Norway. Norsk Polarinstitult. Skrifter, Nr. I I4.

Howarth, P. J. Unpublished. Studies on the lower Tunsbergdal glacier. [Undergraduate thesis, University of Cambridge, ig63.]

Kasser, P. 196. I. Glaziologischer Kommentar zur neuen im Herbst I957 aufgenommenen Karte I : I0.0oo des Grossen Aletschgletschers Union Géodésique et Géophysique Internationale. Association Internationale d'Hydrologie Scientifique. Assemblée généraie de Helsinki, 25-7-6-8 1960. Commission des Neiges et Glaces, p. $216-23$.

Kick, W. 1962. Variations of some central Asiatic glaciers. Union Géodésique et Géophysique Internationale. Association Internationale d'Hydrologie Scientifique. Commission des Neiges et Glaces. Colloque d'Obergurgl, 10-9-18-9 1962, p. 223-29.

Kick, W., and Dorrer, E. 1964. Photogrammetrische Gletschermessungen in Norwegen. Allgemeine VermessungsNachrichten, Jahrg. 71, Ht. i1, p. 422-32.

Kosiba, A. I96o. Some of [the] results of glaciological investigations in SW-Spitsbergen carried out during the Polish I.G.Y. Spitsbergen expeditions in 1957, 1958 and 1959. Nauka o Ziemi I, Uniwersytet Wroclawski im. Bolestawa Bieruta Zeszyty Naukowe Nauki Przyrodnicze, Ser. B, No. 4.

Liestøl, O. [1963.] Noen resultater av bremålinger i Norge 1962. Norsk Polarinstitutt. Arbok 1962, p. 187-90.

Maddever, R. S. Unpublished. Tunsbergdalsbre 1960: an interim report of the work of the Group since 1957 . [Hectographed manuscript. Ambleside, Westmorland, ig6r.]

Meier, M. F. 1960. Mode of flow of Saskatchewan Glacier, Alberta, Canada. U.S. Geological Survey. Professional Paper 351 .

Meier, M. F. 1962. Proposed definitions for glacier mass budget terms. Fournal of Glaciology, Vol. 4, No. 33, p $252-63$.

Meier, M. F., and Tangborn, W. V. I 965 . Net budget and flow of South Cascade Glacier, Washington. Fournal of Glaciology, Vol. 5, No. 41, p. 547-66.

Ostrem, G., and Karlén, V. [1963.] Nigardsbreens hydrologi i962. Norsk Geografisk Tidsskrift, Bd. I8, Ht. 3-4, I962, p. $156-202$.

Ostrem, G., and Liestol, O. 1964[a]. [Field work.] Norway. Ice, No. 15, p. 4-7.

Ostrem, G., and Liestøl, O. $1964[\mathrm{~b}]$. Glasiologiske undersøkelser i Norge 1963 . Norsk Geografisk Tidsskrift, Bd. I8, Ht. $7-8$, I $96 \mathrm{I}-62$, p. $28 \mathrm{I}-340$.

Ht. 7-8, I961-62, p. $28 \mathrm{I}-340$.
Pillewizer, W. 1950. Bewegungsstudien an Gletschern des Jostedalsbre in Südnorwegen. Erdkunde, Bd. 4, Ht. 3-4,

p. 20I-06.
Pillewizer, W. 1952. Beobachtungen am Jostedalsbre in Südnorwegen. Zeilschrift für Gletscherkunde und Glazialgeologie, Bd. 2, Ht. 1, p. 25-34.

Pillewizer, W. 1956. Der Rakhiot-Gletscher am Nanga Parbat im Jahre 1954. Zeitschrift für Gletscherkunde und Glazialgeologie, Bd. 3, Ht. 2, p. $18 \mathrm{I}-94$.

Regensburger, K. 1963 . Comparative measurements on the Fedtschenko Glacier. Bulletin de l'Association Internationale d'Hydrologie Scientifique, 8e An., No. I, p. 57-6r.

Rogstad, O. $195 \mathrm{I}$. Variations in the glacier mass of Jostedalsbreen. Journal of Glaciology, Vol. I, No. I0, p. 55 I-56.

Seue, C. de. 1870 . Le névé de Justedal et ses glaciers. Christiania, S. A. Sexe. [Here quoted according to Hoel and Norvik, 1962.]

[Union Géodésique et Géophysique Internationale.] 1963. Colloque d'Obergurgl (suite). Bulletin de l'Association Internationale d'Hydrologie Scientifique, 8e An., No. 2, p. 50-142. 


\section{APPENDIX}

\section{Work on Tunsbergdalsbreen by the Brathay Exploration Group}

By M. C. L. Herring, P. J. Howarth, R. J. Lorimer, R. S. Maddever, J. F. Nye, A. B. Ware and D. C. Willatts

It may be useful to add that glaciological work has been carried out on Tunsbergdalsbreen by parties of the Brathay Exploration Group each summer since 1956 under the leadership of G. de Boer, W. G. Jenkins, R. J. Lorimer, R. S. Maddever, H. H. Mills, A. B. Ware and G. T. Wright. The main purpose has been to provide training for the boys involved. The primary scientific task was to measure the longitudinal strain-rate down the glacier by repeated annual surveys of a longitudinal line of markers. This has now been done for seven successive years. The line extended for almost the whole length of the tongue $(8 \mathrm{~km}$.) and attempts were made to extend it into the firn region. Measurements of the horizontal component of velocity, of surface slope, and hence of longitudinal surface curvature have also been made with a view to testing correlations with longitudinal strain-rate suggested by theory. The results of these and other measurements on the glacier will be reported later. 